\title{
FAKTOR PENENTU RISIKO SAHAM PERBANKAN DI INDONESIA (Studi pada Industri Perbankan yang Terdaftar di Bursa Efek Indonesia)
}

\author{
Muhammad Madyan, Astriani Wahyuningati, Novian Abdi Firdausi \\ Departemen Manajemen Fakultas Ekonomi dan Bisnis Universitas Airlangga \\ Departemen Ekonomi Islam Fakultas Ekonomi dan Bisnis Universitas Airlangga \\ novianfirdausi@gmail.com
}

\begin{abstract}
This research aims to analyse and asses the effect of credit portfolio, income diversification, total asset, non-performing loan, foreign ownership, short-term loan, and noninterest income to banking industry stock risk in Indonesia. This study uses financial statements data from 25 banks that go public in 2009-2013 year period. Stock risk calculated using deviation standard of return share. Study results show that non-interest income, total asset, non-performing loan, and income diversification have significant effects on bank stock risk. Whereas short-term loan, foreign ownership, and loan portfolio have no significant effects on bank stock risk in Indonesia.
\end{abstract}

Keywords: stock risk, credit portfolio, banking.

\begin{abstract}
Abstrak: Penelitian ini bertujuan untuk menganalisis dan menguji pengaruh portofolio kredit, diversifikasi pendapatan, total asset, non-performing loan, foreign ownership, short term loan, dan non-interest income terhadap risiko saham pada industri perbankan di Indonesia. Data yang digunakan adalah laporan keuangan 25 perbankan go public dalam jangka waktu 2009-2013. Risiko saham diukur menggunakan standar deviasi dari return saham. Hasil penelitian ini menunjukkan bahwa variabel non-interest income, total asset, non-performing loan, dan diversifikasi pendapatan berpengaruh signifikan terhadap risiko saham perbankan. Sedangkan variabel short-term loan, foreign ownership, dan portofolio kredit berpengaruh negatif tetapi tidak signifikan terhadap risiko saham perbankan.
\end{abstract}

Katakunci: Portofolio Kredit, Perbankan. Risiko Saham

Industri perbankan berkembang sepanjang dekade terakhir ini, kegiatan usaha bank yang meningkat berpotensi menyebabkan makin tingginya risiko yang akan dihadapi. Peningkatan risiko yang ada perlu diimbangi oleh peningkatan modal yang diperlukan oleh bank untuk menanggung kemungkinan timbulnya kerugian (Mawardi, 2004).

Selain faktor kinerja bank secara individual, kondisi ekonomi global juga berperan penting (Ling $\mathrm{Wu}$ et al, 2007). Kondisi perekonomian global yang tidak menentu membuat saham-saham perbankan mengalami ketidakpastian khususnya di negara-negara berkembang seperti Indonesia. Menurut Sanya \& Wolfe (2010), kinerja saham turut dipengaruhi faktor-faktor eksternal, khususnya terkait dengan negaranegara dengan perekonomian yang sedang berkembang (emerging economies) dapat diuntungkan dengan adanya diversifikasi. Karakter perusahaan seperti ukuran (size) dan strategi perusahaan serta kondisi makroekonomi di negara-negara berkembang merupakan faktor penting untuk mengontrol dampak diversifikasi.

Tandelilin (2010) menyatakan diversifikasi (portofolio) dapat bermakna bahwa investor perlu membentuk portofolio melalui pemilihan kombinasi sejumlah asset yang sedemikian rupa sehingga risiko dapat diminimalisir tanpa mengurangi return saham yang diharapkan. Salah satunya diversifikasi yang dilakukan oleh bank, sebagian besar bank dapat mengurangi risiko mereka dengan diversifikasi pendapatan.

Dalam Gurbuz et al (2013) ditemukan pengaruh positif antara diversifikasi pendapatan dengan risiko operasional perbankan. Sebuah bank mendapatkan keuntungan dari diversifikasi aktivitas mereka dengan tidak hanya terpaku dalam lending activities saja. Bank yang melakukan diversifikasi pendapatan dapat mengurangi 
biaya operasional serta dapat meningkatkan laba perusahaan.

Namun Elsas (2010) menyatakan bahwa pengukuran-pengukuran diversifikasi yang telah ada kurang bisa dijadikan tolak ukur pengaruh diversifikasi secara keseluruhan. Karena hal inilah maka perlu dikembangkan penelitian-penelitian untuk mengukur pengaruh diversifikasi.

Tujuan dari penelitian ini adalah menganalisis dan menguji pengaruh portofolio kredit, diversifikasi pendapatan, total asset, non performing loan, foreign ownership, short term loan, dan non-interest income terhadap risiko saham perbankan di Indonesia.

Research gap dalam penelitian ini adalah menguji pengaruh faktor penentu risiko saham dengan memasukkan variabel dari neraca (loan) dan laporan laba/rugi (income) dalam satu model. Diversifikasi kredit (credit portofolio) menggunkan pengelompokan jenis-jenis maturitas yang ada di Indonesia yakni kredit jangka pendek, kredit jangka menengah, dan kredit jangka panjang. Untuk variabel diversifikasi pendapatan (income diversivication), yang digunakan hanya dua sumber pendapatan yakni interest income dan non-interest income.

\section{METODE}

Pendekatan penelitian yang digunakan adalah kuantitatif dengan alat analisa Multiple Regression. Dimulai dengan uji asumsi klasik Normalitas, Autokorelasi, Multikolinearitas, dan Heteroskesdasitas

Jenis data yang digunakan adalah data sekunder yang dirangkum dari laporan keuangan tahunan bank-bank umum Indonesia yang terdaftar di Bursa Efek Indonesia dalam kurun waktu 2009-2013, sehingga metode pengambilan sampel menggunakan teknik purposive sampling, yakni pengambilan sampel dengan batasanbatasan dan pertimbangan tertentu sebagai berikut:

1. Perbankan yang terdaftar di Bursa Efek Indonesia dalam kurun waktu 2009-2013.

2. Perbankan yang mempublikasikan laporan keuangan tahunan sejak tahun 2009 hingga 2013

3. Memiliki komponen indikator-indikator perhitungan yang dibutuhkan penelitian.

Hipotesis penelitian diringkas sebagai berikut:

1. Total Asset berpengaruh negatif terhadap risiko saham perbankan

2. Short-Term Loan berpengaruh negatif terhadap risiko saham perbankan

3. Portofolio Kredit berpengaruh positif terhadap risiko saham perbankan

4. Non-Interest Income berpengaruh positif terhadap risiko saham perbankan

5. Diversifikasi Pendapatan berpengaruh positif terhadap risiko saham perbankan

6. Non-Performing Loan berpengaruh positif terhadap risiko saham perbankan

7. Foreign Ownership berpengaruh negatif terhadap risiko saham perbankan

Model analisis disusun untuk mengetahui faktor penentu apa saja yang mempengaruhi risiko saham perbankan, model regresi yang digunakan adalah :

$\mathrm{RISK}_{\mathrm{i}, \mathrm{t}}=\beta_{0}+\beta_{1} \ln \left(T A_{\mathrm{i}, \mathrm{t}-1}\right)+\beta_{2} \operatorname{SHLOANS}_{\mathrm{i}, \mathrm{t}-1}+$ $\beta_{3}$ PORTLOAN $_{\mathrm{i}, \mathrm{t}-1}+\beta_{4}$ NONII $_{\mathrm{i}, \mathrm{t}-1}+$ $\beta_{5}$ DIVINC $_{\mathrm{i}, \mathrm{t}-1}+\beta_{6} N P L_{\mathrm{i}, \mathrm{t}-1}+\beta_{7}$ FOREIGN $_{\mathrm{t}}+$ $\mathrm{e}_{\mathrm{i}, \mathrm{t}}$

Keterangan :

$\ln \left(\mathrm{TA}_{\mathrm{i}, \mathrm{t}-1}\right) \quad$ : Total asset bank i pada periode t-1

SHLOANS $_{\mathrm{i}, \mathrm{t}-1}$ : Short-term loan bank i pada periode $\mathrm{t}-1$

PORTLOAN $\mathrm{i}_{\mathrm{t}, \mathrm{-}-1}$ : Portofolio Kredit maturitas bank i pada periode $\mathrm{t}-1$

$\mathrm{NONII}_{\mathrm{i}, \mathrm{t}-1} \quad$ : Non-Interest Income bank $\mathrm{i}$ pada periode $\mathrm{t}-1$

DIVINC $_{\mathrm{i}, \mathrm{t}-1} \quad$ : Konsentrasi diversifikasi pendapatan bank i pada periode $\mathrm{t}-1$

NPL $_{\mathrm{i}, \mathrm{t}-1} \quad$ : Non-performing loan bank $\mathrm{i}$ pada periode $\mathrm{t}-1$

FOREIGN $_{\mathrm{t}}$ : Prosentase struktur kepemilikan asing pada periode $\mathrm{t}$

RISK $_{\mathrm{i}, \mathrm{t}} \quad$ : Standar deviasi return saham bank i pada periode $\mathrm{t}-1$ 


\section{HASIL}

Hasil rangkuman analisis regresi linier berganda dilakukan untuk mengetahui pengaruh variabel-variabel bebas terhadap risiko saham perbankan (SDEV) pada perusahaan-perusahaan perbankan yang go public di Bursa Efek Indonesia (BEI) pada tahun 2009-2013

Tabel 1. Hasil Analisis Regresi Linier Berganda

\begin{tabular}{lccc}
\hline \multicolumn{1}{c}{ Model } & Koefisien & t & Sig. \\
\hline Konstanta & 0,358 & 2,729 & 0,007 \\
\hline TA & $-0,012$ & $-3,716$ & 0,000 \\
\hline SHLOAN & $-0,042$ & $-1,408$ & 0,162 \\
\hline PORTLOAN & $-0,050$ & $-1,086$ & 0,280 \\
\hline NONII & 0,268 & 2,929 & 0,004 \\
\hline DIVINC & 0,130 & 2,210 & 0,029 \\
\hline NPL & 0,784 & 2,009 & 0,047 \\
\hline FOREIGN & $-0,002$ & $-0,102$ & 0,919 \\
\hline R & 0,535 & & \\
\hline R Square & 0,286 & & \\
\hline F & 6,580 & \\
\hline Sig.F & 0,000 & \\
\hline Var. Terikat & RISK \\
\hline
\end{tabular}

Sumber : Data diolah

Berdasarkan tabel 1 diatas, persamaan regresi linier berganda yang dihasilkan adalah:

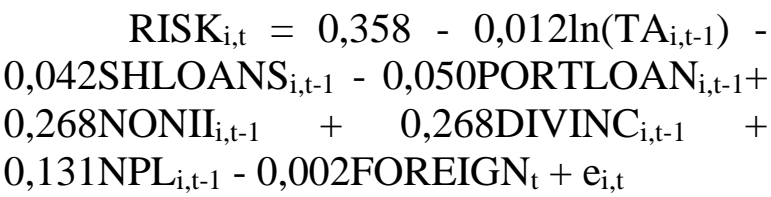

Penjelasan persamaan regresi linier berganda di atas adalah sebagai berikut:

Angka konstanta sebesar 0,358 menunjukkan jika variabel bebas yang terdiri dari Total Asset, Short-Term Loan, Portofolio Kredit Diversifikasi Pendapatan, Non-Interest Income, Non-Performing Loan, dan Foreign Ownership sama dengan nol, risk (risiko saham) perbankan bernilai sebesar 0,358.

Variabel Total Asset (TA), Non Interest Income (NONII), Diversifikasi Pendapatan (DIVINC), dan Non Performing Loan (NPL) berpengaruh signifikan terhadap risiko saham perbankan karena nilai signifikansi sebesar $<0,05$. Sedangkan variabel Short Term Loan (SHLOAN), Portofolio Kredit (PORTLOAN), dan Foreign Ownership (FOREIGN) tidak berpengaruh signifikan terhadap risiko saham perbankan.
Nilai koefisien determinasi sebesar 0,286 menunjukkan bahwa risiko saham (SDEV) sebagai variabel dependen dapat dijelaskan sebesar $28,6 \%$ oleh variabelvariabel total asset, short term loan, portofolio kredit, non interest income, diversifikasi pendapatan, non performing loan, dan foreign ownership, sedangkan $71,4 \%$ dapat dijelaskan oleh variabel lain diluar model.

Nilai signifikansi $\mathrm{F}$ yang dihasilkan sebesar 0,000 menunjukkan bahwa secara bersama-sama variabel-variabel total asset, short term loan, portofolio kredit, non interest income, diversifikasi pendapatan, non performing loan, dan foreign ownership berpengaruh signifikan terhadap risiko saham perbankan, implikasinya model ini dapat dikatakan cukup baik untuk memprediksi risiko saham perbankan.

\section{PEMBAHASAN \\ Pengaruh Total Asset}

Variabel total asset berpengaruh negatif dan signifikan terhadap risiko saham perbankan. Semakin besar total asset sebuah bank, maka semakin kecil risiko saham yang ditanggung oleh investor. Hal ini juga sesuai dengan Ozsoz (2013), Mawardi (2004), dan Stever et al (2005). jika bank bisa mengelola dananya secara tepat, maka harta perusahaan yang tercermin dalam total asset juga akan bertambah. Semakin besar total asset suatu bank, maka semakin besar kemampuan bank untuk melakukan diversifikasi, sehingga memperkecil risiko operasional bank yang nantinya dapat menurunkan risiko saham yang dihadapi oleh para investor.

\section{Pengaruh Short Term Loan}

Variabel Short term loan berpengaruh negatif dan tidak signifikan terhadap risiko saham perbankan. Hal ini mendukung penelitian Ozsoz (2013) yang juga menemukan pengaruh negatif dan tidak signifikan short-term loan terhadap risiko saham perbankan.

Dapat disimpulkan bahwa semakin tinggi short-term loan suatu bank, maka semakin rendah risiko saham yang ditanggung oleh investor. Keberadaan industri yang memiliki tingkat ketidakpastian yang tinggi sebagai pemakai utama short-term loan 
membuat pengaruh variabel ini pada risiko saham perbankan menjadi tidak signifikan.

\section{Pengaruh Portfolio Kredit}

Portofolio kredit diukur dengan Herfindahl Hirschman Index yang didasari oleh maturitas kredit, menunjukkan pengaruh negatif dan tidak signifikan terhadap risiko saham perbankan. Hasil ini mendukung Ozsoz (2013) yang juga menemukan pengaruh tidak signifikan variabel portofolio kredit terhadap risiko saham. Pemberian kredit merupakan salah satu aktivitas perbankan yang paling utama dalam menghasilkan profit, tetapi salah satu risiko yang terbesar dalam perbankan juga bersumber dari pemberian kredit (Dendawijaya, 2000).

Bank memiliki strategi portofolio kredit yang berbeda-beda. Jika manajer mampu merumuskan strategi portofolio kredit yang tepat, maka bank dapat menghemat biaya yang timbul dalam rangka memperoleh pendapatan. Semakin terdiversifikasinya kredit suatu bank, maka biaya yang dibutuhkan semakin banyak. Sebaliknya, jika semakin tidak terdiversifikasinya kredit suatu bank, semakin sedikit pula biaya yang dibutuhkan (Ali, 2006).

Pengaruh yang tidak signifikan dari variabel ini dapat disebabkan karena dalam pelaksanaannya, informasi tentang Herfindahl Hirschman Index yang didasari oleh maturitas kredit tidak tersedia di pasar sehingga investor tidak mempertimbangkan faktor Herfindahl Hirschman Index dalam pengambilan keputusan investasi (Al-Muharrami, 2008). Bisa dikatakan bahwa investor memilih pertimbangan faktor-faktor kredit berdasarkan laporan yang dipublikasikan oleh bank.

\section{Pengaruh Non-Interest Income}

Hasil penelitian menunjukkan noninterest income memiliki pengaruh positif dan signifikan terhadap risiko saham perbankan. Artinya, semakin besar jumlah non-interest income, maka semakin tinggi pula risiko saham perbankan. Hasil ini mendukung Hidayat (2012) yang menemukan pengaruh positif dan signifikan non-interest income terhadap risiko, namun berbeda dengan $\mathrm{Ozsoz}$ (2013) yang menemukan pengaruh tidak signifikan dari non-interest income terhadap risiko perbankan.

Akhir-akhir ini perbankan berlomba untuk mengoptimalkan teknologi informasi dalam rangka meraup konsumen sebanyakbanyaknya meskipun pengembangan teknologi akan menyerap biaya yang sangat tinggi. Hal ini dilakukan karena konsumen bank cenderung memilih bank yang memiliki fasilitas teknologi yang baik untuk mendapatkan kemudahan dalam proses kegiatan operasional. Namun persaingan yang tinggi membuat bank harus memiliki keunggulan lebih dalam memasarkan produkproduknya (Kasmir, 2012).

Risiko yang tinggi akibat persaingan produk jasa perbankan menyebabkan turunnya kepercayaan investor untuk berinvestasi. Sehingga investor menghadapi risiko saham yang tinggi pula sebagai akibat dari ketidakpastian pendapatan yang bersumber dari non-interest income.

\section{Pengaruh Diversifikasi Pendapatan}

Diversifikasi pendapatan yang diukur dengan Herfindahl Hirschman Index memiliki pengaruh positif dan signifikan terhadap risiko saham perbankan. Semakin terkonsentrasinya pendapatan suatu bank, maka semakin tinggi pula risiko sahamnya. Hal ini sesuai dengan William (2010), Mercieca et al (2006), dan Stiroh (2005) yang juga menemukan pengaruh positif dan signifikan terhadap risiko.

Dengan bervariasinya jenis kegiatan usaha yang ada di masyarakat dapat mempengaruhi variasi jenis-jenis kredit yang ditawarkan oleh perbankan. Hal ini merupakan upaya pihak perbankan untuk melaksanakan diversifikasi produk perbankan yang ditawarkan kepada masyarakat. Hal ini merupakan cerminan usaha yang dilakukan bank untuk meminimalisir risiko yang potensial dalam persaingan yang kompetitif.

Selain itu, pihak perbankan dapat melayani kebutuhan dana dan permodalan kepada para calon debitur secara tepat. Semakin tepat diversifikasi pendapatan yang dimiliki suatu bank, semakin efektif pula komposisi sumber pendapatan yang mampu meningkatkan pendapatan perusahaan, sehingga memperkecil risiko saham yang ditanggung oleh investor (Sudirman, 2013). 


\section{Pengaruh Non-Performing Loan}

Hasil penelitian menemukan bahwa non-performing loan berpengaruh yang positif dan signifikan terhadap risiko saham perbankan. Artinya, semakin tinggi rasio kredit bermasalah dalam suatu bank, maka semakin tinggi pula risiko sahamnya. Hasil penemuan ini mendukung Ozsoz (2013) dan Arif (2012) yang juga menemukan pengaruh positif dan signifikan antara non-performing loan terhadap risiko saham bank.

Semakin besar jumlah saldo kredit bermasalah yang dimiliki bank, semakin besar pula jumlah dana cadangan yang harus disediakan, begitu juga biaya yang harus ditanggung untuk mencukupi biaya cadangan tersebut. Kredit bermasalah yang membengkak akan menurunkan profitabilitas bank (Mawardi, 2004). Bank harus terpaksa mengurangi jumlah modal sendiri, yang selanjutnya mengakibatkan penurunan persentase Capital Adequacy Ratio (CAR). Terbukti dengan menurunnya rasio NonPerforming Loan mampu meningkatkan jumlah Capital Adequacy Ratio.

Upaya investor untuk memperoleh return yang lebih tinggi mendorong perbankan untuk mengembangkan credit appraisal techniques secara tepat. Semakin efektif credit appraisal technique suatu bank, akan menurunkan rasio non-performing loan-nya, sehingga memperkecil risiko saham yang dihadapi oleh investor.

\section{Pengaruh Foreign Ownership}

Struktur Foreign Ownership memiliki pengaruh negatif yang tidak signifikan terhadap risiko saham perbankan. Hal ini tidak sesuai dengan Oszoz (2013) yang menunjukkan pengaruh signifikan negatif foreign ownership terhadap risiko saham perbankan. Pengaruh yang tidak signifikan variabel foreign ownership dapat disebabkan oleh kebijakan-kebijakan yang diterapkan di Indonesia.

Berbagai kebijakan dirumuskan sebagai respon dari meningkatnya ketidakpastian perekonomian global. Pemerintah dan Bank Indonesia menerapkan kebijakan-kebijakan tertentu dalam menghadapi situasi ini. Kebijakan yang ditempuh Bank Indonesia dan pemerintah berkontribusi positif untuk mengurangi tekanan stabilitas ekonomi dan mendorong penyesuaian ekonomi tetap terkendali ke arah yang lebih seimbang. Bank Indonesia menetapkan kebijakan makroprudensial sebagai bagian dari strategi bauran kebijakan.

Kebijakan-kebijakan khusus yang dikeluarkan oleh pemerintah dapat berpengaruh positif atau negatif pada perusahaan tertentu yang terkait dengan kebijakan tersebut. Misalnya peraturan giro wajib minimum yang mempengaruhi likuiditas perbankan. Semakin tinggi giro wajib minimum yang ditetapkan pemerintah, maka bank juga harus meningkatkan jumlah aset-aset likuid untuk menjaga tingkat likuiditasnya.

Perbankan harus mengikuti kebijakan pemerintah dalam penentuan besaran tingkat suku bunga. Bank umum tidak boleh menawarkan produk pendanaannya dengan tingkat bunga yang lebih tinggi dari BI rate (Ismail, 2010). Kepemilikan asing dapat mengurangi informasi asimetri yang kemudian memperkecil risiko saham perbakan. Namun dengan adanya kebijakankebijakan pemerintah yang diluar kontrol perusahaan dapat membuat pengaruh variabel ini terhadap risiko saham menjadi tidak signifikan.

\section{KESIMPULAN DAN SARAN Kesimpulan}

Terdapat beberapa kesimpulan yang didapatkan dari penelitian ini, yaitu:

1. Total asset terbukti mampu menurunkan risiko saham yang dihadapi perbankan. Hal ini ditunjukkan dengan pengaruh total asset yang negatif terhadap risiko saham perbankan. Semakin besar jumlah kekayaan yang dimiliki suatu bank, maka semakin kecil risiko saham yang dihadapi investor.

2. Short-term loan tidak terbukti menurunkan risiko saham sebagai akibat dari rendahnya suku bunga dan singkatnya jangka waktu. Nasabah pengguna short-term loan kebanyakan berasal dari industri yang risiko ketidakpastiannya cukup besar. Sehingga short-term loan berpengaruh tidak signifikan terhadap risiko saham.

3. Portofolio kredit tidak terbukti dapat menurunkan risiko saham perbankan. 
Informasi mengenai Herfindahl

Hirschman Index yang tidak tersedia di pasar menjadi faktor penyebab variabel portofolio kredit tidak berpengaruh signifikan terhadap risiko saham perbankan.

4. Non-interest income dalam jumlah besar dapat meningkatkan risiko saham perbankan. Hal ini dapat dilihat dari noninterest income yang berpengaruh positif terhadap risiko saham perbankan.

5. Semakin terkonsentrasinya komposisi pendapatan bank, maka semakin tinggi pula risiko saham yang timbul. Hal ini ditunjukkan oleh diversifikasi pendapatan yang berpengaruh positif terhadap risiko saham perbankan.

6. Non-performing loan berpengaruh positif terhadap risiko saham perbankan. Semakin tinggi tingkat kredit bermasalah yang dimiliki bank, semakin besar kemungkinan investor dalam menghadapi risiko saham.

7. Berbagai kebijakan yang diterapkan pemerintah dan Bank Indonesia dalam menghadapi ketidakpastian perekonomian global membuat pengaruh foreign ownership tidak signifikan.

\section{Saran}

Berdasarkan kesimpulan yang dihasilkan dari penelitian ini, maka :

1. Pemerintah diharapkan menerapkan kebijakan melalui bank sentral yang sesuai dengan kondisi perekonomian Indonesia saat ini sehingga industri perbankan mampu menghindari kemungkinan risikorisiko yang dihadapi. Jika perbankan kinerjanya baik, maka pelaksaanaan kebijakan moneter akan berjalan baik. Sehingga bank sentral sebagai lembaga penanggungjawab kebijakan moneter dapat menjalankan fungsinya dengan baik.

2. Para investor diharapkan mampu lebih selektif dalam memilih perusahaan untuk tujuan investasi. Investor dapat membantu kinerja bank melalui hak suara yang dimiliki dan turut serta merumuskan kebijakan-kebijakan yang dapat menjaga kesehatan bank yang bersangkutan.

3. Manajer bank perlu membangun strategi pengelolaan bank secara baik agar bank dapat menghindari risiko-risiko yang berimbas pada kepercayaan investor. Jika bank memiliki kinerja yang baik, maka penilaian investor akan baik pula, sehingga bank dapat meminimalisir risiko saham yang mungkin terjadi.

4. Bagi nasabah agar lebih selektif dalam memilih produk-produk perbankan, nasabah juga harus bisa bekerja sama dengan bank yang sudah dipercaya demi terciptanya kelancaran peningkatan kinerja. Jika bank memiliki kinerja yang baik, maka dapat mempermudah kegiatan penyaluran dana.

\section{DAFTAR RUJUKAN}

Ali, M. Haji. 2006. Manajemen Risiko: Strategi Perbankan dan Dunia Usaha Menghadapi Tantangan Globalisasi Bisnis. Jakarta: PT Raja Grafindo Persada

Al Muharrami, Saeed. 2008. The Competition and Market Structure in the Saude Arabian Banking. Saudi Arabia: Journal of Economic Studies Vol.36 No.5

Arif, Ahmed \& Ahmed Nauman Anees. 2012. Liquidity Risk and Performance of Banking System. Journal of Financial Regulation and Compliance Vol.20 No. 2

Dendawijaya, Lukman. 2000. Manajemen Perbankan. Jakarta: Ghalia Indonesia

Elsas, Ralf et al. 2010. The Anatomy Of Bank Diversification. Journal of Banking \& Finance, Vol. 34

Gurbuz, Ali Osman et al. 2013. Income Diversification \& Bank Performance : Evidence from Turkish Banking Sector. BDDK Bankacilik ve Finansal Piyasalar: Vol.7 No.1

Hidayat, Yuana Wahyu, dkk. 2012. Bank Risk and Non-Interest Income Activities in the Indonesian Banking Industry. Indonesia : Journal of Asian Economics Vol.23

Ismail. 2011. Manajemen Perbankan : Dari Teori Menuju Aplikasi. Edisi Pertama. Jakarta : Kencana.

Kasmir. 2012. Bank \& Lembaga Keuangan Lainnya. Jakarta: PT Raja Grafindo Persada

Ling wu, Hsiu. 2007. The Impact of Financial Development and Bank Characteristics 
on The Operational Performance of Commercial Banks in The Chinese Transitional Economy. Taiwan: Journal of Economic Studies, Vol.34 No.5

Mawardi, Wisnu. 2004. Analisis FaktorFaktor Yang Mempengaruhi Kinerja Keuangan Bank Umum di Indonesia. Tesis. Semarang. Universitas Diponegoro

Mercieca, Steve et al. 2007. Small European banks: Benefits From Diversification?. European: Journal of Banking \& Finance Vol.31

Ozsoz, Emre et al. 2013. What Determines Return Risks for Bank Equities in Turkey. SSRN Electronic Journal

Sanya, Sarah \& Simon Wolfe. 2010. "Can Banks in Emerging Economies Benefit from Revenue Diversification?. USA : J Financ Serv Res Vol. 40

Stever, Ryan et al. 2005. Bank Size, Credit and The Sources Of Bank Market Risk. University of California, Berkeley

Stiroh, J. Kevin. 2006. New evidence on the Determinants of Bank Risk. USA: Springer Science

Sudirman, I Wayan. 2013. Manajemen Perbankan: Menuju Bankir Konvensional Yang Profesional. Edisi Pertama. Jakarta: Kencana

Tandeilin, E. 2010. Portfolio dan Investasi : Teori dan Aplikasi. Edisi Pertama. Yogyakarta : Kanisius

William, Barry \& Laurie Prather. 2010. Bank Risk and Return : The Impact of Bank Non-Interest Income. International Journal of Managerial Finance, Vol.6 No.3 